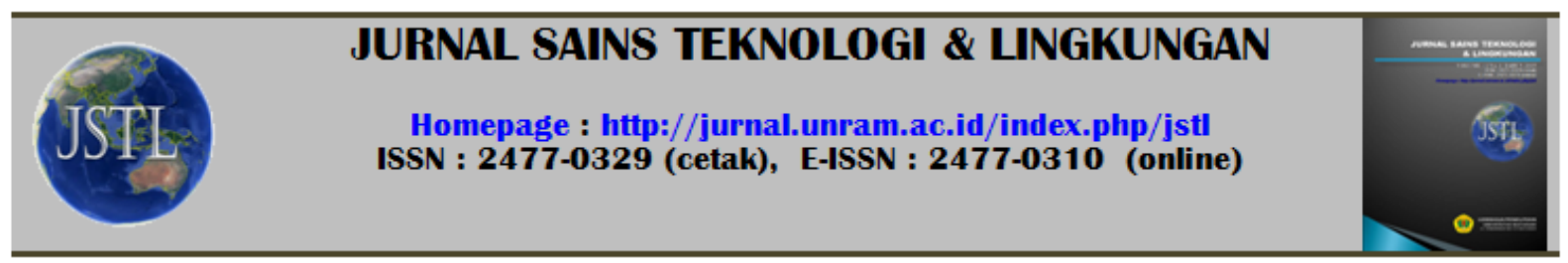

\title{
DETEKSI WSSV (WHITE SPOT SYNDROM VIRUS) PADA LOBSTER AIR TAWAR (PROCAMBARUS CLARKII) MENGGUNAKAN METODE REAL TIME-PCR
}

\author{
${ }^{1)}$ Nefi Andriana Fajri, ${ }^{2)}$ Muhammad Ali dan ${ }^{2}$ Sulaiman N. Depamede \\ $\left.{ }^{1}\right)$ Laboratorium Mikrobiologi Manajemen sumberdaya Peternakan Pasca Sarjana Fakultas Peternakan \\ Universitas Mataram \\ ${ }^{2)}$ Fakultas Peternakan Universitas Mataram
}

\begin{tabular}{l} 
Kata kunci : \\
\hline White Spot \\
Syndrome \\
Virus, Lobster \\
Air Tawar, \\
RT-PCR
\end{tabular}

\begin{abstract}
Abstrak
Serangan virus White Spot Syndrome (WSSV) telah memberikan dampak finansial yang cukup besar sejak tahun 1992. Tingkat mortalitas yang mencapai $100 \%$ menyebabkan banyak pembudidaya udang dan lobster menderita kerugian. Untuk mengatasi permasalahan tersebut sangat diperlukan informasi tentang cara penyebaran virus WSSV sehingga dapat diketahui solusi yang tepat untuk menghentikan penyebarannya pada tambak-tambak udang maupun lobster. Pada penelitian ini, Lobster Air Tawar yang dibudidayakan di BBI Aik Bukak dijadikan kontrol negatif (belum terinfeksi virus WSSV). Hasil penelitian ini menunjukkan bahwa penularan virus WSSV pada lobster air tawar dapat berlangsung melalui konsumsi udang yang telah terinfeksi virus WSSV serta melalui aliran air. Pleopod atau kaki renang yang dideteksi dengan teknologi Real Time Polimerase Chain Reaction (RT-PCR) mengandung virus WSSV yang lebih dominan dibandingkan insang
\end{abstract}

\begin{tabular}{ll}
\hline Key words : & Abstract \\
\hline White Spot & White Spot Syndrome virus (WSSV) Attacks has provided substantial financial impact since \\
Syndrome & 1992. The mortality rate reaches 100\% causing many farmers of shrimp and lobster suffered \\
Virus, & financial losses. To overcome these problems information on how the spread of the virus \\
Freshwater & extreemely needed in order to stop the spread in ponds of shrimp and lobster. In this study, \\
cryfish, RT- & Freshwater cryfish cultivated in Aik Bukak Fish Breeding Center (BBI Aik Bukak) used as a \\
PCR & negative control (not infected with the WSSV). The results indicate that the transmission of \\
& the White Spot Syndrome Virus on crayfish can take place through the consumption of shrimp \\
& that has been infected with WSSV and through the flow of water. Pleopod or swimming foot \\
& detected by Real Time Polymerase Chain Reaction (RT-PCR) technology containing WSSV \\
& more dominant than the gills.
\end{tabular}




\section{PENDAHULUAN}

Perkembangan terkini di bidang biologi molekuler telah memberikan kemudahan di berbagai bidang kehidupan manusia. Deteksi penyakit yang semula berbasis keberadaan antigen-antibodi, mulai ditingkatkan spesifikasinya dengan menggunakan tehnik molekuler yaitu Polymerase Chain Reaction (PCR). Tehnik ini telah mampu mereduksi terjadinya "false positive" pada deteksi beberapa jenis penyakit yang selama ini dilakukan dengan tehnik Enzyme-linked Immunosorbent Assay (ELISA). (Pestana et al, 2010)

PCR dapat digunakan untuk menentukan keberadaan suatu penyebab penyakit (patogen) dan dapat digunakan untuk menentukan kandungan materi genetik baik DNA maupun RNA. Dalam beberapa tahun terakhir ini, pengunaan teknologi PCR telah dikembangkan menjadi tehnik Real Time Polymerase Chain Reaction (Real Time PCR). Deteksi hasil dalam Real Time-PCR langsung di kuantifikasi oleh perangkat lunak (software) pada komputer. Keunggulan penggunaan tehnik ini, diantaranya: (1) lebih cepat, (2) lebih sensitivif, dan (3) lebih spesifik, dan (4) dapat mengetahui kuantitas pathogen.

Pada penelitian ini dilakukan deteksi penyakit bercak putih atau white spot syndrome pada lobster air tawar, dengan menggunakan Real Time PCR. Di Indonesia, penyakit WSSV mewabah sejak tahun 1995 dan menyerang udang hingga $100 \%$ kematian selama 3- 10 hari sejak gejala klinis muncul. Namun, di Indonesia penelitian mengenai penyakit WSSV belum banyak dilakukan baik dalam aspek penularan maupun pencegahannya (Alifuddin et al., 2003). Dalam deteksi penyakit tersebut, penggunaan tehnologi Real Time-PCR memungkinkan untuk mengetahui jumlah salinan (copy) dari virus tersebut.

\section{METODOLOGI PENELITIAN Materi Penelitian}

Materi penelitian yang dipergunkan dalam penelitian ini adalah lobster air tawar jenis Procambarus Clarkii. Sebagai pakan penginfeksi, digunakan udang vannamei (Litopenaeus vannamei) yang positif terinfeki virus WSSV. Untuk pakan noninfeksi digunakan wortel.

\section{Metode Penelitian}

Perlakuan dan Proses Penanganan Sampel

Pada Penelitian ini lobster air tawar diberikan tiga macam perlakuan, masing-masing perlakuan dengan dua ulangan sebagai berikut :

Perlakuan 1: Lobster air tawar diberikan pakan wortel dipelihara dalam dua aquarium, masingmasing aquarium berisi 10 ekor lobster air tawar. Perlakuan II: Lobster air tawar diberikan pakan udang vanamei yang positif terinfeksi WSSV, dipelihara dalam dua aquarium, masing-masing aquarium berisi 10 ekor lobster air tawar. Perlakuan III: Lobster air tawar diberikan pakan wortel dipelihara dalam dua aquarium yang airnya berasal dari aquarium perlakuan II.

\section{Isolasi Jaringan}

Pada penelitian ini lobster yang digunakan untuk isolasi jaringan sudah berumur lebih dari 1,5 bulan dengan panjang badan \pm 13 $14,5 \mathrm{~cm}$, untuk itu bagian tubuh yang dijadikan untuk isolasi jaringan DNA cukup diambil pada bagian pleopod dan insang seperti yang disarankan oleh Supriatna (2013).

\section{Ekstraksi DNA}

Ekstraksi DNA pada lobster air tawar menggunakan metode CTAB-DTAB (IQ2000 ${ }^{\circledR}$ ).

\section{Amplifikasi DNA}

Tahap Pengenceran terhadap standar positif WSSV $(\mathrm{P}(+))$ dengan membuat 5 tingkat pengenceran berturut-turut yaitu $10^{5}, 10^{4}, 10^{3}$, $10^{2}$, dan $10^{1}$. Pengenceran dimulai dengan mengambil sebanyak $1 \mu$ l kontrol positif $\mathrm{P}(+)$ $10^{4}$ (stok) dipindahkan ke dalam tube dengan kode $10^{3}$, kemudian ditambahkan $9 \mu 1 \mathrm{dd}_{2} \mathrm{O}$ sebanyak $1 \mu \mathrm{l}(+)$ Standar $10^{3}$ dipindahkan ke dalam tube dengan kode $10^{2}$, kemudian ditambahkan $9 \mu \mathrm{l} \mathrm{ddH}_{2} \mathrm{O}$, begitu seterusnya hingga konsentrasi 5.

Menyiapkan Master Mix PCR: Semua reagen diencerkan terlebih dahulu pada suhu ruang, vortex \pm 5 detik, lalu spin sebentar agar reagen tercampur rata. Masukkan $20 \mu \mathrm{l}$ master mix ke dalam masing-masing well. Kemudian tambahkan $8 \mu \mathrm{l}$ sampel DNA dan $8 \mu$ l kontrol positif serta $8 \mu$ l RT-PCR grade water $\left(\mathrm{ddH}_{2} \mathrm{O}\right)$ untuk NTC (kontrol negatif).

Setting Siklus PCR: dengan mengatur suhu, waktu dan jumlah siklus dalam tahapan-tahapan PCR. 


\section{Variabel yang diamati}

Variabel-variabel yang diamati dalam penelitian ini adalah :

\section{HASIL DAN PEMBAHASAN Pengamatan Gejala Klinis}

Hasil pengamatan menunjukkan aktifitas berenang lobster pada masing-masing perlakuan berbeda antara perlakuan I, II dan III. Pada perlakuan I tidak ada menunjukkan gejala, pada perlakuan II lobster air tawar yang terinfeksi virus WSSVcenderung berenang ke arah tepi secara bergerombol, pergerakan pasif, dan terlihat lemah, sedangkan pada perlakuan III gejalanya terlihat setelah 18 hari pasca infeksi.

Pada perlakuan I, sisa pakan dalam aquarium terlihat tidak ada. Sedangkan pada perlakuan II, sisa pakan sudah mulai terlihat pada hari ke 3 pasca infeksi, dan pada perlakuan III sisa pakan mulai terlihat hari ke 10 pasca infeksi. Pada hari ke 10, lobster air tawar pada perlakuan II sudah ada yang mati. Kematian total lobster pada perlakuan tersebut terjadi pada hari ke 13 pasca infeksi. Hasil penelitian ini berbeda dengan penelitian yang dilakukan oleh Wang et al (1998) yang menyatakan bahwa lobster jenis $P$. clarkii akan mati total dalam 18 hari setelah terinfeksi virus WSSV. Adanya perbedaan ini antara lain disebabkan oleh tingkat infeksi virus yang dialami oleh lobster air tawar yang ditentukan jumlah konsumsi udang terinfeksi lebih banyak.

Lobster pada perlakuan III (air aquariumnya dialirkan dari aquarium lobster yang diberikan pakan udang yang terinfeksi virus WSSV pada perlakuan II) mengalami kematian pada hari ke 15 pasca infeksi. Hasil pengamatan memperkuat hasil penelitian Chang et al, (1996) bahwa virus WSSV mampu menyebar melalui kanibalisme maupun melalui air yang terkontaminasi oleh virus. Secara fisik sampel lobster air tawar tidak menunjukkan adanya gejala klinis terserang virus WSSV, yaitu tidak adanya bintik putih pada bagian tubuh (karapas) untuk itu perlu dilakukan uji lebih lanjut dengan menggunakan PCR Konvensional dan Real Time-PCR.

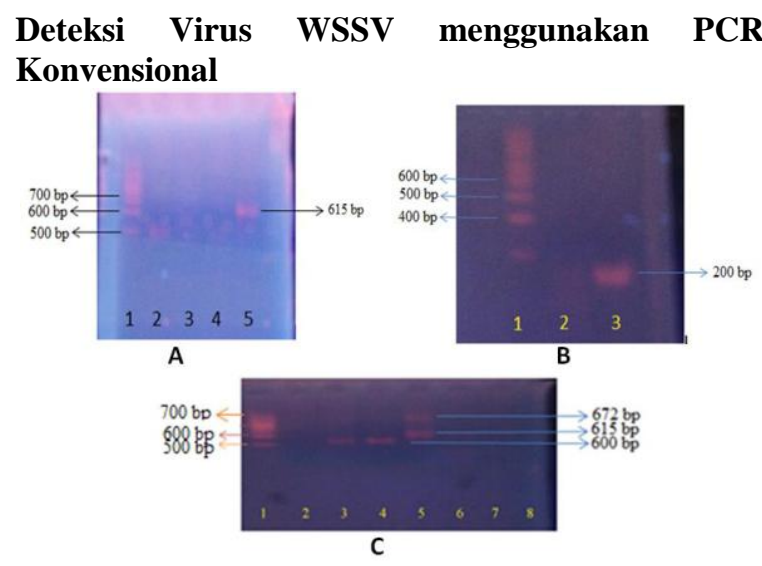

Keterangan:

Gambar a. Hasil PCR konvensional terhadap sampel lobster control (Perlakuan I)

Keterangan: $1=$ Marker, 2-4=Kontrol (Perlakuan I). $3=$ Kontrol Positiv Virus WSS stok

Gambar b. Hasil PCR konvensional terhadap sampel lobster Positif terinfeksi WSSV (Perlakuan II)

Keterangan: $1=$ marker, $2=$ kontrol negatif (bufer

PBS), 3 = kontrol positif (virus WSS stok), 4-8 = sampel lobster yang mati dan diduga terserang virus WSS.

Gambar c. Hasil PCR konvensional terhadap sampel lobster (Perlakuan III)

Keterangan: 1=Marker, 2=Kontrol, 3= Sampel Lobster pada Perlakuan III

Pada perlakuan I (Gambar 1) sampel lobster control yang diambil dari BBI Aik Bukak Lombok Tengah tidak ditemukan adanya virus WSSV yang menginfeksi lobster air tawar, sedangkan hasil visualisasi pita DNA pada gel agarose perlakuan II menunjukkan adanya pita pada sampel lobter air tawar yang terinfeksi virus WSSV (Gambar 5b, nomer 3 dan 4). Hal ini menunjukkan bahwa pada sampel tersebut terdeteksi adanya virus WSSV yang berarti sampel lobster positif terserang virus WSSV (Perlakuan II), dan pada perlakuan III (airnya dialiri dari perlakuan II) ditemukan adanya virus WSSV yang menginfeksi lobster air tawar pada perlakuan III sebanyak 1 ekor, baik pada pleopod maupun kaki renang.

Deteksi virus WSSV dengan Real Time PCR Amplifikasi DNA virus WSSV secara otomatis oleh software Rotor Gene Q Series secara lebih spesifik digambarkan dalam bentuk kurva standard dan grafik amplifikasi.Titik pada kurva standar (Gambar 2) menunjukkan beberapa tingkat pengenceran yang masing-masing memiliki nilai $\mathrm{Ct}$ (Threshold cycle) yaitu siklus PCR saat kurva amplifikasi memotong garis threshold. Garis threshold merupakan garis deteksi Real Time PCR. Nilai untuk garis 
threshold dapat secara otomatis ditentukan oleh Software PC atau dapat dihitung secara manual dengan mengalikan $5 \%$ dari nilai tertinggi batas amplifikasi (Prasetyo, 2009).

Line Threshold $=5 \% \mathrm{x}$ batas tertinggi amplifikasi

Rumus untuk menghitung Nilai garis threshold

Kurva standar dari amplikasi sampel lobster air tawar dengan pengenceran $10^{5,} 10^{4}, 10^{3}$, adalah sebagai berikut:

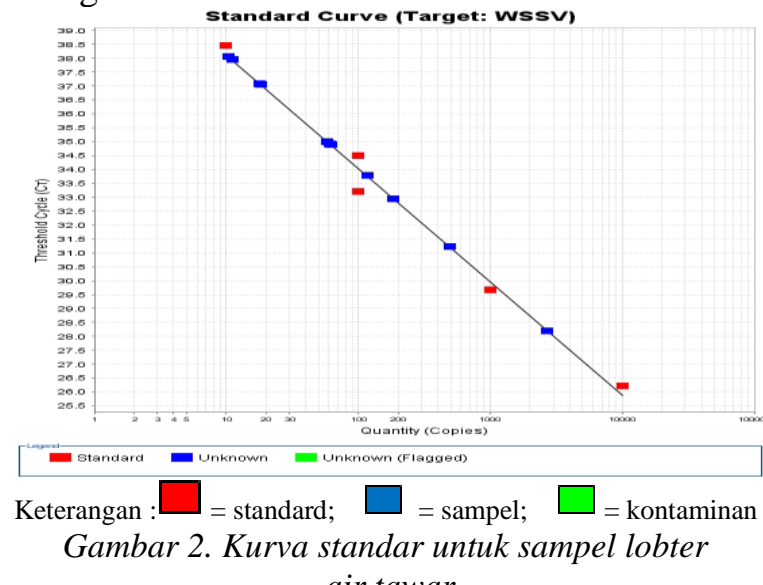
air tawar

Adanya gradien garis pada kurva standar menunjukkan ketepatan kuantitas DNA virus yang diperoleh dan kualitas pengenceran yang telah dilakukan. Semakin kecil standar pengenceran yang dilakukan, semakin akurat hasil yang akan diperoleh. Namun, resiko bergesernya standar positif pada gradien garis kurva standar semakin besar sehingga tidak menunjukkan kuantitas DNA virus yang diharapkan. Hal tersebut biasanya disebabkan oleh kualitas pengenceran yang kurang optimal. Pada kurva standard pengenceran ekstraksi DNA (gambar 2) dapat dilihat sampel isolate lobster air tawar sudah bagus karena tidak ada yang terkontaminasi, bisa dilihat dari sampel yang sudah masuk dalam garis lurus pada kurva standar. Kurva standar isolat lobster air tawar memiliki nilai slope $-4,078$, nilai $Y$-Intercept 42, 918 dan nilai $\mathrm{R}^{2} 0,986$, sedangkan menurut Pestana et al. (2010) sebuah kurva standar dengan standar positif harus memiliki kriteria nilai slope di antara $-3,1$ sampai -3.8 dan nilai $\mathrm{R}^{2}$ $>0,980$. Nilai slope sampel yang berasal dari isolate lobster bernilai $-4,078>-3,8$, ini menunjukkan nilai slope sudah hampir mendekati dari nilai standar slope. Dalam pengujian terdapat 23 well masing-masing sesuai letak sampel pada plate PCR. Terdapat 18 sampel, dan 5 kontrol positif (+), Selain itu, dapat dilihat kuantitas dari DNA virus yang teramplifikasi dan nilai perpotongan garis threshold (Threshold Cycle $\left(\mathrm{C}_{\mathrm{T}}\right)$ ) dari masingmasing sampel dalam siklus PCR. Hal tersebut menunjukkan adanya deteksi DNA WSSV yang diperoleh pada sampel tersebut. Untuk lebih jelasnya ditunjukkan pada grafik.

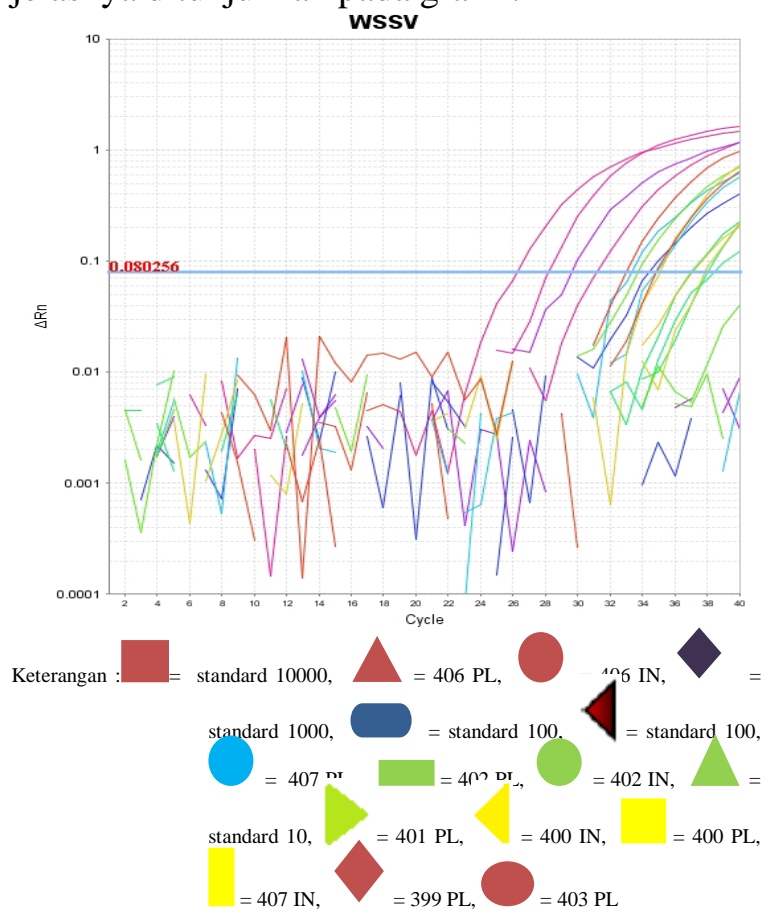

Gambar 3. Grafik hasil Real Time-PCR terhadap virus WSS pada sampel lobster air tawar

Berdasarkan hasil deteksi menggunakan Real Time PCR diketahui bahwa dari delapan belas sampel yang di deteksi ada 7 (tujuh) sampel yang tidak positif terinfeksi WSSV dan 11 (sebelas) sampel yang positif terinfeksi WSSV, dapat dilihat pada grafik amplifikasi (Gambar 3).

Grafik amplifikasi merupakan grafik yang menunjukkan keberadaan DNA hasil amplifikasi (Wijayati dan Fahris 1999).Adanya infeksi suatu penyakit atau hasil positif pada grafik amplifikasi ditandai dengan adanya akumulasi pada sinyal fluorescen dan melintasi base line threshold (Koesharyani, et. al, 2008). Dari grafik amplifikasi hasil uji, sampel dengan kode 399PL, 400PL, 400IN, 401PL, 401IN, 402PL, 402IN, 403PL, 406PL, 406IN, 407PL, 407IN (Gambar 3) yang melintasi garis 
threshold sedangkan sampel dengan kode 399IN, 401IN, 403IN, 404PL, 404IN, 405PL, dan 405IN, tidak melintasi garis threshold. Kode sampel uji yang tidak melintasi garisthreshold menunjukkan hasil negative sedangkan yang melewati garis threshold menunjukkan hasil positif. Grafik amplifikasi sampel uji dan kurva standar berbentuk sigmoid yang terdiri atas beragam warna yang masingmasing menunjukkan fragmen DNA WSSV sampel uji yang teramplifikasi.

\section{Bagian Tubuh Lobster Air Tawar Yang Paling Banyak Mengandung Virus WSSV}

Berdasarkan hasil deteksi virus WSS pada dua organ tubuh lobster air tawar diketahui bahwa dari delapan belas sampel yang di deteksi ada beberapa sampel yang negatif terinfeksi WSSV dan ada bagian dari tubuh lobster air tawar yang tidak terdeteksi virus WSSV. Pada pengujian Real Time PCR terdapat beberapa sampel yang tidak terdeteksi, disampel kode 399 pada insang, 401 pada insang, 403 pada insang dan Sampel kode 404 dan 405 positif tidak terinfeksi WSSV baik pada insang maupun pleopot.

Hasil deteksi menunjukkan bahwa terdapat virus WSS pada pleopod atau kaki renang lebih banyak dibandingkan dengan insang yaitu sampel 390PL dengan kuantitas virus WSSV sebanyak 184.4857 copy, 400PL sebanyak 17.9088 copy, 400IN sebanyak 58.4634 copy, 401PL sebanyak 116.1588 copy, 402PL, sebanyak 18.1145 copy, 402IN sebanyak 10.372 copy 403PL sebanyak 60.6218 copy 406PL sebanyak 2720.3105 copy, 406IN sebanyak 491.6056 copy 407PL sebanyak 62.0582 copy dan 407IN dengan kuantitas virus WSSV sebanyak 11.0368 copy. Jelas terlihat bahwa pada pleopod atau kaki renang yang paling banyak mengandung virus WSS dibandingkan insang. Seperti yang dilaporkan oleh Wang et al (1998) organ target WSSV itu adalah pleopod, insang, perut, otot abdominal, hemolin, usus, hati, pleopod, organ limfoid, erpidermis, organ saraf, hepatopankreas, testes, ovary, spermatophorus dan tangkai mata, dan menurut (Lightner, 1996) organ Target WSSV adalah epitilium kutikula dan jaringan ikat pada insang, sel epitelia subkutikular, limfoid, kelenjar antenna, dan hemolin. Tetapi infeksi WSSV jarang terjadi pada epitelium kelenjar antenna, sel sarung organ limfoid, simpul syaraf dan hepatopankreas.

Pada penelitian ini lobster air tawar dapat tertular dari air sebagai pembawa, pada perlakuan III yang airnya dialiri dari perlakuan II (yang diberikan pakan udang positif terinfeksi WSSV) positif terinfeksi virus WSSV baik pada pleopod maupun insang. Penyebaran penyakit WSSV dapat disebabkan oleh adanya organisme carrier, yaitu organisme pembawa penyakit yang dapat menularkan penyakit pada organisme lainnya, tetapi organisme carrier tersebut tidak menunjukkan gejala klinis penyakitnya tapi tibatiba sampel uji mati. Untuk mengatasi dampak virus ini, diperlukan pengetahuan mengenai transmisi infeksi virus WSSV terutama pada tingkat molekuler untuk dapat melakukan intervensi terhadap patogenisitasnya sehingga penanganan dapat dilakukan secara tuntas dan efisien.

\section{KESIMPULAN}

Berdasarkan hasil penelitian dan pembahasan dapat ditarik kesimpulan sebagai berikut: Lobster Air TAwar yang dibudidayakan di BBI Aik Bukak (dijadikan kontrol pada penelitian ini belum terinfeksi virus WSSV); Penularan virus WSS pada lobster air tawar dapat berlangsung melalui konsumsi udang yang telah terinfeksi virus WSS serta melalui aliran air; Pleopod atau kaki renang dideteksi mengandung virus WSSV yang lebih peka dibandingkan insang..

\section{DAFTAR PUSTAKA}

Chang, P.S., Chen, H.C., and Wang, Y.C. 1998.Detection of White Spot SyndromeAsociated Baculovirus in Eksperimentally Infected Wild Shrimp, crab andLobsters by inSitu Hybridization Aquacult.164233242.

Dieffenbach, C.W., T.M. J.Lowe, \& G.S. Dveksler.1993. General Concepts for PCR Primer Design. PCR Methods Application 3:30-37.

Fatimi, Humairah. 2010. Polymerase Chain Reaction (PCR). Palembang : Program Studi Ilmu Biomedik Program Pasca Sarjana, Universitas Brawijaya. 
Irawati.2008, Penambahan ekstrak wortel (Daucus carrota L) pada pakan untuk meningkatkan pertumbuhan dan tingkat kelangsungan hidup lobster air tawar(Cherax quadricarinatus).Thesis. Universitas Erlangga. Surabaya

Kasornchandra J, Boonyaratpalin S, Itami T (1998) Detection of white-spot syndrome in cultured penaeid shrimp in Asia: microscopic observation and polymerase chain reaction. Aquaculture 164:243-251

Kiiyuki, C. 2003. Laboratory Manual of Food Microbiology for Ethiopian Health and Nutrition Reasearch Institute (Food Microbiology Laboratory). Unido Project: 28-33, 75-80

Koesharyani isti, Tatik Mufidah, Hambali Supriyadi, Hessy Novita , 2008, Infeksi Infectious Myonecrosis Virus (IMNV) Pada Budidaya Udang Vaname (penaeus Vannamei) Di Jawa Timur.: 945-949

Lightner, D.V. 1996a.A Handbook of Shrimp Pathology and Diagnostic Procedures for Diseases of Cultured penaeid Shrimp. The World Aquaculture Society. Baton Rouge, Louisiana, 70803 USA.

Lightner, D.V. 1996b.Epizootiology, distribution and the impact on international trade of two penaeid shrimp viruses in the Americas. Revue Scientifique et Technique Office International des Epizooties 15: 579-601.

Lio-Po, G.D., Albright, L.I., Traxler, G.S. and Leano, E.M. 2001.Pathogenicity of The Epizooeic Ulcerative Syndrome (EUS)-Associated Rhabdovirus to Snakehead Ophicephalus Striatus. Fish Pathology 36, 57-66.

Lo C.F., Ho C.H., Peng S.E., Chen C.H. and 7 others. 1996. White Spot Syndrome Baculovirus (WSBV) Detected in Cultured and Captured
Shrimp, Crabs and Other Arthropods. Dis Aquat Org 27:215225

Lorenz, T. 1998. A Review of Carotenoid, Astaxanthin, as a Pigment and Vitamin Source for Cultured Penaeus Prawn. http://www.cyanotech.com. 7 hal. . 2000. Natu Rose TM Natural Astaxanthin as a Carotenoid and Vitamin Source for Ornamental Fish and Animals. http://www.cyanotech.com. 8 hal.

Madeali, M. I., A. Tompo dan Muliani. 1998. Diagnosis Penyakit Viral Pada Udang Windu, Penaeus monodon Secara Histopatologis dan Antibody Poliklonal Dengan Metode Elisa. Jurnal Penelitian Perikanan Indonesia, 4 (3): 11-18.

Mahardika, K., Zafran dan I. Koesharyani. 2004. Deteksi White Spot Syndrome Virus (WSSV) Pada Udang Windu (Penaeus monodon) di Bali dan JawaTimur Menggunakan Metode Polymerase Chain Reaction (PCR). JurnalPenelitian Perikanan Indonesia, 10 (1): 55-60.

Martens, T.R. \& R.L. Hammersmith. 1995. Genetics Laboratory Investigation. 10th ed. Prentice-Hall, Englewood Cliffs: vii +277 hlm.

Sánchez-Paz, A., 2010. White spot syndrome virus: an overview on an emergent concern. Veterinary Research, 41, 43.

Pestana, E.A., S. Belak., A. Diallo., J.R. Crowther., G.J. Viljoen. 2010. Early Rapid and Sensitive Veterinary Moleculer Diagnostics - Real Time PCR Applications. Springer. Dordrecht Heidelberg, London New York

Pranawaty, R.N., Buwono, I.D., dan Liviawaty, E. 2012.Aplikasi Polymerase Chain Reaction (PCR) Konvensional dan Real Time PCR Untuk Deteksi White Spot Syndrome Virus Pada Kepiting.Jurnal 
Perikanan dan Kelautan. Vol. 3(4):61-74.

Prasetyo, A., 2009. Materi Asistensi Biomedik FK UNS. FK UNS. Semarang

Prijanto, Muljati. 1992. Polymerase Chain Reaction (PCR) untuk Diagnosis Human Immunodeficiency Virus $(H I V)$. http://www.pcr.htm. Diakses 1 Mei 2014.

Polanski, A. \& M. Kimmel. 2007. Bioinformatics. Springer, Berlin: $\mathrm{xvii}+376 \mathrm{hlm}$.

Sambrook, J. \& D.W. Russell. 2001. Molecular Cloning: A Laboratory Manual. $3^{\text {rd }} e d$. CSHL Press, New York: xxvii +18 .

Tonsakun, F., Siwaporn, L., S. Rukpratarnporn, $\quad \mathrm{P}$. Chaivisuthangkura, W. Sithigornul, and P. Sithigorngul. 2006. Experimental Infection of Three PalaemonidShrimps With White

Wang, Y. G., M. Shariff, P.M. Sudha, P.S. Srinivasa Rao, M.D. Hassan and L.T. Tan. 1998. Managing white spot disease in shrimp, Infofish International.p : 30-36.

Wang, C. S., Y. J. Tsai, G. H. Kou and S. N. Chen. 1997. Detection of White SpotSyndrome Disease Virus Infection in Wild Caught Greasyback Shrimp, Metapenaeus Ensis (deHaan) in Taiwan. Fish Pathology, 32 (1): 35-41.

Weeden, N. F., Timmerman, G. M., Hemmat, M., Kneen, B. E., dan Lodhi, M. A. 1992.Inheritance and reliability of RAPD markers.In Application of RAPD technology to plant breeding, symposium Proceedings, Crop Science Of America, Madison, W. I., p.12-17.

Wijayati, A., dan N. Fahris. 1999. Teknik Deteksi Serangan Virus. Pelatihan Petugas Pengamat Penyakit.

Balai Besar Pengembangan
Budidaya Air Payau (BBPBAP).Jepara.8 hlm.

Yuwono, T. 2006. Teori dan Aplikasi Polymerase Chain Reaction. Penerbit Andi: Yogyakarta. Spot Syndrome Virus (WSSV).Department of Biology, Faculty of Science, Srinakharinwirot University, Bangkok. 